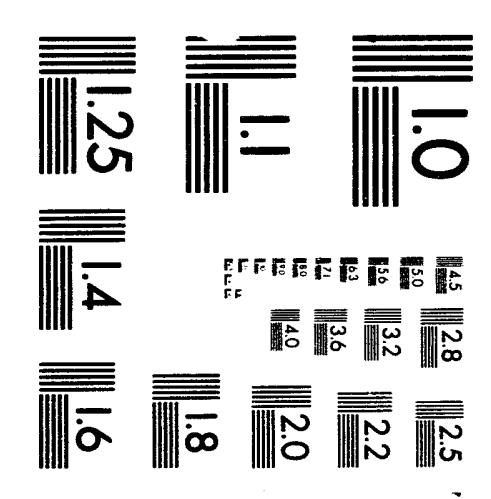



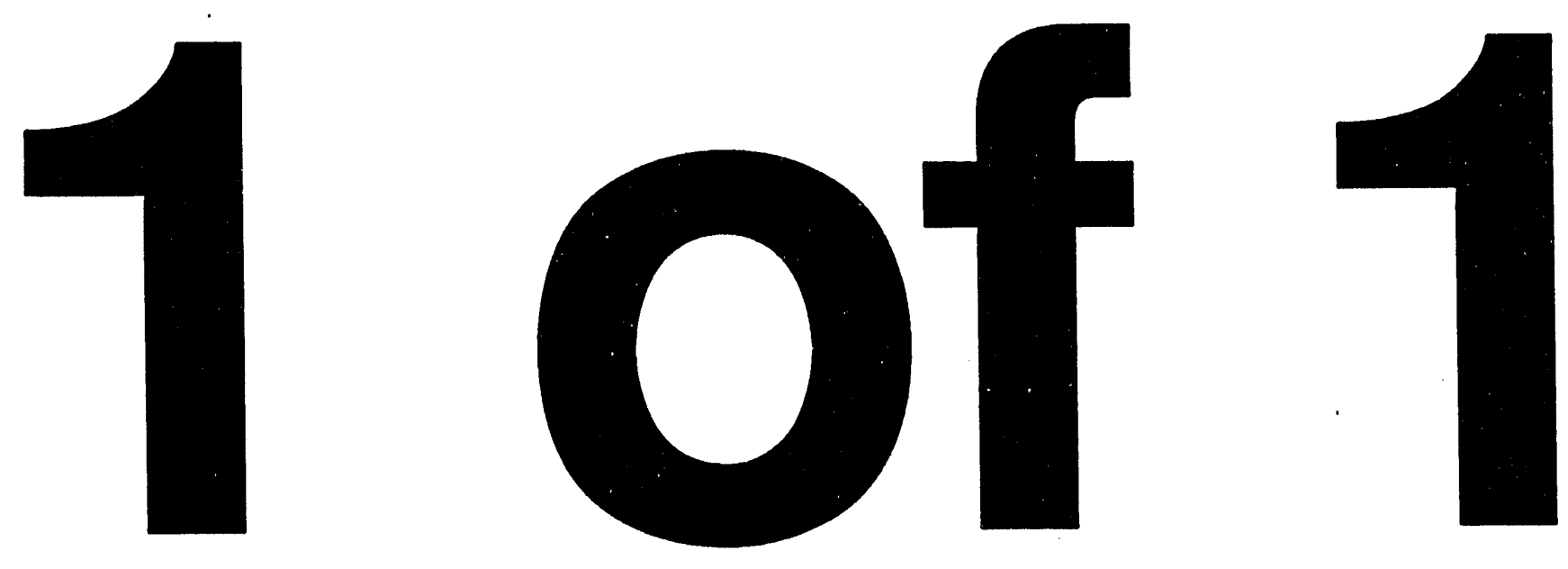


\title{
Proposal for the Completion of Outstanding Work on the Installation Scheduling and Alignment of the SDC Central Calorimeter ${ }^{\dagger}$
}

\author{
Victor Guarino, Norman Hill, James Nasiatka, \\ Emil Petereit*, and Lawrence Price \\ High Energy Physics Division \\ Argonne National Laboratory, Argonne, Illinois
}

November 18, 1993

\section{Introduction}

The High Energy Physic Division at Argonne National Laboratory was given the task of developing the procedures, fixtures, and schedules for the final assembly of the barrel and endcap calorimeters for the SDC. The work completed led to some major decisions about how and where this assembly work would be done. The primary assembly decision was the feasibility of assembling the major detector components (barrel and endcap sub-assemblies) above ground and lowering them into position in the experimental hall, as opposed to assembling the calorimeter directly in the experimental hall. Due to cost of above ground assembly and schedule changes, the in-hall option was adopted. Although no actual hardware was constructed, many conceptual ideas were formalized and brought to workable solutions as a result of the effort put forth at ANL.

MASTER

* E. Petereit is a member of the Argonne Engineering Physics Division.

$\dagger \quad$ Work supported by the U.S. Department of Energy, Division of High Energy Physics, Contract W-31-109-ENG-38. 


\section{Proposal}

The ANL High Energy Physics Division proposes to close out this program by documenting the work that was done in order to provide an understanding of the requirements of assembly, installation, and alignment of such large and complex devices as the barrel and endcap calorimeters, the complexity of integrating them into the SDC detector, and to show some insight to the reasoning behind the decisions that were made.

\section{Work Completed to Date}

1) Above Ground Assembly Scenario

A. Determined space requirements in order to construct sub-assemblies in the IR-8 assembly building for designs set forth in the TDR, Title I, and Title II proposals [Refs. 1-6].

B. Determined safety-related requirements for calorimeter assembly [Refs. 1-6].

C. Scheduling for calorimeter assembly including module arrival at IR-8, testing, storage, and installation into calorimeter [Refs. 5-6].

D. Reviewed Title I design proposal for the IR-8 assembly building and found several problems [Refs. 7-9].

E. Determined manpower and equipment requirements in the IR-8 assembly building for the period between JOD and BOD [Ref. 10].

2. In-Hall Assembly Scenario

A. Performed layout of preliminary space requirements to assembly calorimeters in-hall [Refs. 4-5].

3. Calorimeter Installation Scheduling

A. Initial schedule based on above ground assembly, showing module arrival at IR-8, testing, storage, and installation into calorimeter subassembly [Refs. 5-6].

B. Started dialog between other SDC groups (Muon, Tracker, Integration, etc.) to determine space and scheduling requirements for in-hall assembly [Refs. 11-13]. 


\section{Alignment}

A. Set up initial guidelines and requirements for calorimeter sub-assem-

bly alignment to themselves, to the other subsystems, and module

alignment during installation into calorimeter sub-assembly [Ref. 14].

5. Installation Fixture Design

A. Conceptual design for module storage stands [Refs. 15 and 17].

B. Conceptual design for moveable test stands.

C. Conceptual design for installation/rotation fixtures [Refs. 16-17, 22].

i. Initial drawings

ii Calculations

6. Calorimeter Assembly Analysis

A. Finite element analysis of the barrel calorimeter [Refs. 18-19].

B. Finite element analysis of the endcap calorimeter [Refs. 18-21].

\section{Estimate of Effort to Complete Task}

\begin{tabular}{|l|c|c|r|}
\hline Name & Effort & Duration & Cost \\
\hline N. Hill & .1 & 1 month & $\$ 1270$ \\
\hline J. Nasiatka & 1.0 & 1 month & $\$ 12,708$ \\
\hline
\end{tabular}

\section{Cost}

The cost of completing this task is confined to the effort shown.

\section{Schedule}

Work to be completed in the first quarter of FY94. 


\section{REFERENCES}

1. ANLHEP Drawing Number SDCINST2, Calorimeter Installation Layout.

2. ANLHEP Drawing Number SDCINST3, Calorimeter Installation Layout.

3. ANLHEP Drawing Number SDCINST4, Calorimeter Installation Layout.

4. ANLHEP Drawing Number SDCINST5, Calorimeter Installation Layout.

5. SDC Collaboration Meeting Presentation on Detector Integration, J. Nasiatka and N. Hill, October 1-2, 1992.

6. "Surface Assembly of the SDC Calorimeter", J. Nasiatka, October 1992.

7. ANLHEP Drawing Number TITLEI, IR-8 Assembly Building Title I Design Layout.

8. Memo to P. Mantsch on "SDC Assembly Building - Title I Design Proposal," J. Nasiatka and N. Hill, September 1, 1992.

9. Memo to T. Kirk on "SDC Assembly Building Crane Height," J. Nasiatka and N. Hill, November 11, 1992.

10. Memo to T. Winch on "IR-8 Assembly Building," J. Nasiatka, February 2, 1993.

11. Presentation to the SDC Integration Meeting at Fermilab on Space and Scheduling Requirements for In-Hall Assembly, J. Nasiatka and N. Hill, June 10, 1993.

12. "Assembly Schedule - Master," Master In-Hall Assembly Schedule for Entire SDC Collaboration, J. Nasiatka, June 14, 1993.

13. "Above Ground Assembly Hall", IR-8 Asembly Building Schedule for SDC Calorimeters, J. Nasiatka, June 14, 1993.

14. Memo to T. Winch, P. Mantsch, J. Missig, and J. Carson on "SDC Barrel and Endcap Alignment Systems," J. Nasiatka, October 1993.

15. ANLHEP Drawings 34-402-56-0 through 8, 34-402-56-A, and 34-402-56-P, SDC-BCAL, Cosmic Ray Test Sta:d.

16. ANLHEP Drawing Number SSC-3010, Barrel Module Installation and Rotation Fixture. 
17. Memo to T. Winch on "Calorimeter Assembly Procedures," J. Nasiatka, September 30, 1993.

18. "Finite Element Analysis of the SDC Barrel and Endcap Calorimeters," V. Guarino, N. Hill, and J. Nasiatka, SDC-92-222, and ANL-HEP-TR-92-20, March 11, 1992.

19. "Mechanical Design and Finite Element Analysis of the SDC Central Calorimeter", V. Guarino, N. Hill, D. A. Hoecker, T. D. Hordubay, J. Nasiatka, D. W. Scherbarth, R. L. Swensrud, ANL-HEP-CP-93-12.

20. Memo to N. Hill on "Endcap Model B Analysis," J. Nasiatka, February 12, 1992.

21. Memo to N. Hill on "Endcap Model G Analysis," J. Nasiatka, February 12, 1992.

22. "Calculations for 'Stress' and Loading on the SDC Installation/Rotating Fixture," J. Nasiatka, August, 1993.

\title{
DISCLAIMER
}

\begin{abstract}
This report was prepared as an account of work sponsored by an agency of the United States Government. Neither the United States Government nor any agency thereof, nor any of their employees, makes any warranty, express or implied, or assumes any legal liability or responsibility for the accuracy, completeness, or usefulness of any information, apparatus, product, or process disclosed, or represents that its use would not infringe privately owned rights. Reference herein to any specific commercial product, process, or service by trade name, trademark, manufacturer, or otherwise does not necessarily constitute or imply its endorsement, recommendation, or favoring by the United States Government or any agency thereof. The views and opinions of authors expressed herein do not necessarily state or reflect those of the United States Government or any agency thereof.
\end{abstract}



